\title{
A bibliometric analysis of greenwashing research: a closer look at agriculture, food industry and food retail
}

Bibliometric analysis of greenwashing

\author{
Antonio Montero-Navarro, Thais González-Torres, \\ José-Luis Rodríguez-Sánchez and Rocio Gallego-Losada \\ Universidad Rey Juan Carlos, Madrid, Spain
}

\begin{abstract}
Purpose - This paper aims at providing an overview and synthesis of the existing body of knowledge about greenwashing. Special attention is paid to the articles directly linked with agriculture, food industry and food retail.

Design/methodology/approach - A bibliometric analysis was performed over 351 documents extracted from the WoS database, using SciMAT and VOSviewer software programs.

Findings - Three periods in the academic literature about greenwashing can be distinguished: ground-setting (2003-2010), trail-blazing (2011-2015) and remarkable growth (2016-2020). Along this evolution, a body of knowledge which stemmed from the literature about CSR has achieved a major development, deploying different research lines such as stakeholders' management, marketing and communication and audit. A specific analysis of the academic literature about greenwashing in agriculture, food industry and food retail has been carried out, showing a need for further development.

Social implications - The development of scientific knowledge about greenwashing puts this social claim on the spotlight of business management studies, helping to fight greenwashing and, this way, to reduce the environmental impact of corporate activities. Studying greenwashing will help to reduce its frequency and, therefore, heal the planet.

Originality/value - Some previous studies have provided systematic reviews of the literature using different approaches, but they did not untangle the intellectual structure and the evolution of the body of research about greenwashing. This article originally provides a thorough analysis of these aspects, as well as a closer look at the impact of greenwashing practices in the academic literature regarding agriculture, food industry and food retail.
\end{abstract}

Keywords Greenwashing, Greenhushing, Agriculture, Food industry, Food retail, Bibliometric analysis,

Co-word analysis

Paper type Research paper

\section{Introduction}

The once traditional sole focus on the financial performance of the organizations is no longer a reality. Nowadays, companies have to deal with the aspirations of many stakeholders, groups which demand a sufficient degree of satisfaction of their goals and interests. Stakeholders like consumers, investors, governments and the society as a whole are increasingly requiring responsible behaviors from companies, as well as demanding transparency in the information about their environmental performance (Chen and Chang, 2013; Marquis et al., 2016). Consequently, green markets — products, services, investment

(C) Antonio Montero-Navarro, Thais González-Torres, José-Luis Rodríguez-Sánchez and Rocio GallegoLosada. Published by Emerald Publishing Limited. This article is published under the Creative Commons Attribution (CC BY 4.0) licence. Anyone may reproduce, distribute, translate and create derivative works of this article (for both commercial and non-commercial purposes), subject to full attribution to the original publication and authors. The full terms of this licence may be seen at http:// creativecommons.org/licences/by/4.0/legalcode

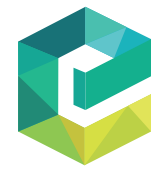

British Food Journal Vol. 123 No. 13, 2021 pp. $547-56$ Emerald Publishing Limited $0007-070 \mathrm{X}$
Received 29 June 2021 Revised 18 August 2021 Accepted 24 September 2021 
$\mathrm{BFJ}$

123,13

\section{8}

opportunities and firms - and responsible disclosure of business information have been expanding rapidly in the last years (Delmas and Burbano, 2011).

The main goal of a responsible disclosure of business information is to communicate the sustainable practices of a firm to its stakeholders, in order to improve its corporate reputation and, thus, influence the stakeholder's behavior towards the company and its products or services. The expected outcomes of these practices are improved financial performance and increased societal gain derived from a change of behavior (Font et al., 2017).

It is in this context that the phenomenon of greenwashing arises. Considering the potential benefits of having an environmentally concerned image, sustainability communication not accompanied by real practices is becoming increasingly frequent (Lyon and Maxwell, 2011). Starting from the initial formulation of Jay Westervelt in 1986, the term greenwashing has become a standard to describe this kind of practices. There are many definitions of the term, such as the one provided by Tateishi (2017), who affirms that it is a type of "communication that misleads people regarding environmental performance/benefits by disclosing negative information and disseminating positive information about an organization, service, or product”.

Along with the social concern about this practice, the academia is paying a growing attention to it, as it raises challenging research opportunities for many academic disciplines (Lyon and Montgomery, 2015).The number of scholarly articles mentioning greenwashing has increased sharply in the last decades, remarkably since 2016. Given the environmental impact of food related activities, greenwashing is also a relevant concern for those who study the policies, actions and behaviors of the main agents involved along the food supply chain (Alons, 2017; DeFries et al., 2017; Guyader et al., 2017).

This article aims at providing an overview and synthesis of research on the notion and practices of greenwashing. This general objective is broken down into the following specific objectives: (1) to assess the academic productivity through the historical evolution of publications; (2) to determine the intellectual structure of the research topic; (3) to uncover the thematic organization of the research topic; and (4) to identify the conceptual structure of the research topic. Along with them, an additional goal would be (5) to analyze the specific research trends concerning greenwashing in agriculture, food industry and food retail.

According to these goals and following recent bibliometric reviews, some research questions can be settled:

$R Q 1$. Which is the historical evolution of the literature about greenwashing?

$R Q 2$. Which are the main documents that have influenced the intellectual structure of the topic?

$R Q 3$. Which are the main journals around which the research topic is organized?

RQ4. Which are the patterns and hot topics in the field of greenwashing?

RQ5. Which are the main concerns boarded by the researchers about greenwashing in agriculture, food industry and food retail?

This article provides academics with an overview of the current situation and trends of this research body. The results of this study are especially relevant considering the importance of the topic of greenwashing and the emphasis of society and institutions in developing a sustainable growth.

\section{Methodology}

In order to answer these research questions and achieve the objectives, this article uses a bibliometric methodological approach, following other relevant works. Bibliometric analysis 
provides the researchers with different tools that help them to assess the academic productivity, its impact and its relative influence; to establish the intellectual structure of the research topic as well as its evolution; and to identify the different subtopics and its conceptual structure (Gomezelj, 2016; Marasco et al., 2018).

The information search strategy has been based on the bibliographic database Web of Science (WoS), one of the most prestigious in the field of social sciences and frequently used for bibliometric studies in management and organization fields. In order to avoid the researchers' subjectivity in data collection, a keyword search has been carried out. The search terms selected were "greenwashing", "greenwash" and "greenhushing". The research included articles, proceedings papers, book chapters and reviews published in peer-reviewed journals included in the database from January 1990 to December 2020.

The number of documents obtained is 360 . All the results have been double-checked by the authors in order to eliminate duplicates and confirming that they fit the object of the study. From this screening, a total of 351 articles were chosen.

Initially, SciMAT software (Cobo et al., 2012) has been used in order to deliver productivity measures about the research field, considering the historical evolution of the publications (RQ1), the most influential ones (RQ2) and the main journals where they have been published (RQ3). The article also includes relational techniques through a bibliometric mapping approach using the VOSviewer software in order to determine the evolution of the intellectual structure of the field of knowledge (RQ4). This software "pays special attention to the graphical representation of bibliometric maps. The functionality of VOSviewer is especially useful for displaying large bibliometric maps in an easy-to-interpret way" (Van Eck and Waltman, 2010, p. 523).

Finally, a specific literature review of 19 articles directly related with greenwashing in agriculture, food industry or food retail has been carried out (RQ5). This selection was carried out by the authors, using a double-check process, after reading the abstract and, when needed, the entire content of each of the 351 papers included in the bibliometric analysis.

\section{Results and discussion}

\subsection{Productivity measures}

Figure 1 shows the growth of the number of academic articles per year in the field of greenwashing. The first publication (Mulligan, 1999) appeared in the Institute Development Studies Bulletin.

When analyzing the number of publications per year, a growth trend can be clearly recognized. We can identify three stages in the development of the academic literature about greenwashing: ground-setting (1999-2010); trail-blazing (2011-2015); and remarkable growth (2016-2020).

The growing environmental awareness of our society has increased academics' interest in the phenomenon of greenwashing as an instrument used by practitioners to improve their strategic positions (Antunes et al., 2015; Wolniak and Habek, 2015). Specially, the years after 2015 have meant a clear burst in the publication of fresh academic literature, roughly accumulating two-thirds $(63.3 \%)$ of the 351 documents. Consequently, it could be said that research in the field of greenwashing is a hot topic that is gaining importance in the recent years.

As can be seen in Table 1, a $28.5 \%$ of the authors are linked with US universities, while some other countries, such as the UK, China, Canada and Germany are also importantly represented. Amongst the top 10 countries we can distinguish two North American ones (US and Canada), some of the main European economies (the UK, Germany, France and Italy), two industrial powers (China and Brazil) and Australia, due to the importance of its natural resources. 
BFJ

123,13

550

Figure 1.

Historical evolution of publications
80

70

60

50

40

40

30

20

0 \begin{tabular}{llllllll|l}
1 & 1 & 3 & 3 & 1 & 1 & 4 & 4 & 4
\end{tabular}

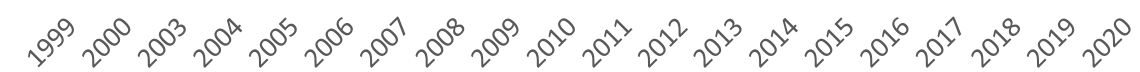
$15 \quad 15 \quad 18$

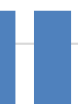

\begin{tabular}{|c|c|c|c|c|c|c|c|c|}
\hline Countries & $N$ & $\%$ & Journal & $N$ & $\%$ & Research areas & $N$ & $\%$ \\
\hline $\begin{array}{l}\text { United } \\
\text { States }\end{array}$ & 100 & $28.5 \%$ & $\begin{array}{l}\text { Journal of Business } \\
\text { Ethics }\end{array}$ & 21 & $6.0 \%$ & $\begin{array}{l}\text { Business } \\
\text { economics }\end{array}$ & 167 & $47.6 \%$ \\
\hline UK & 34 & $9.7 \%$ & $\begin{array}{l}\text { Business Strategy } \\
\text { and the Environment }\end{array}$ & 12 & $3.4 \%$ & $\begin{array}{l}\text { Environmental } \\
\text { sciences ecology }\end{array}$ & 101 & $28.8 \%$ \\
\hline China & 28 & $8.0 \%$ & Sustainability & 11 & $3.1 \%$ & $\begin{array}{l}\text { Social sciences } \\
\text { other topics }\end{array}$ & 52 & $14.8 \%$ \\
\hline Canada & 20 & $5.7 \%$ & $\begin{array}{l}\text { Journal of Cleaner } \\
\text { Production }\end{array}$ & 11 & $3.1 \%$ & $\begin{array}{l}\text { Science } \\
\text { Technology other } \\
\text { topics }\end{array}$ & 43 & $12.3 \%$ \\
\hline Germany & 19 & $5.4 \%$ & $\begin{array}{l}\text { Corporate Social } \\
\text { Responsibility and } \\
\text { Environmental } \\
\text { Management }\end{array}$ & 7 & $2.0 \%$ & Engineering & 28 & $8.0 \%$ \\
\hline Brazil & 18 & $5.1 \%$ & $\begin{array}{l}\text { Environmental } \\
\text { Communication }\end{array}$ & 4 & $1.1 \%$ & Communication & 27 & $7.7 \%$ \\
\hline Italy & 17 & $4.8 \%$ & $\begin{array}{l}\text { Organization } \\
\text { Environment }\end{array}$ & 4 & $1.1 \%$ & Government law & 15 & $4.3 \%$ \\
\hline Australia & 15 & $4.3 \%$ & $\begin{array}{l}\text { Revista Brasileira de } \\
\text { Marketing }\end{array}$ & 4 & $1.1 \%$ & Geography & 10 & $2.8 \%$ \\
\hline France & 12 & $3.4 \%$ & & & & $\begin{array}{l}\text { Public } \\
\text { Administration }\end{array}$ & 8 & $2.3 \%$ \\
\hline Netherlands & 12 & $3.4 \%$ & & & & Sociology & 6 & $1.7 \%$ \\
\hline
\end{tabular}

Table 1. by most influential countries, journals and research areas

10 Netherlands

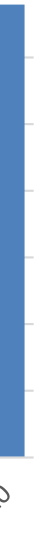

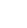


two different areas of concern, being placed in the intersection between business economics and environmental sciences, which can be a proof of a claim for a new and more sustainable way of management.

The 351 articles were written by 808 different authors. The vast majority of them $(92.6 \%$; $n=748 / 808)$ took part in just one publication; $6.1 \%$ of the authors $(n=49 / 808)$ published two ones; and $1.4 \%(n=11 / 808)$ are credited in three or more publications. Table 2 displays the most productive ones, with three or more articles published in this research field.

The relative youth of the academic concern about greenwashing, along with the diversity of perspectives and the alignment with different concerns (management, marketing, production, public policies and environment), has resulted in the existence of many research teams, which are developing their work in different lines. The most prolific authors are Lyon, especially concerned with the information disclosure made by corporations; Chen, mainly focused on the perceptions of the consumers; Testa, who is especially concerned about the role of the stakeholders of a firm; Font, whose works are associated with sustainable tourism; and Siano and Vollero, focused on the communication of CSR actions.

Table 3 shows the articles with the highest number of citations in absolute terms $(>100)$ ordered by citations per year $(\mathrm{C} / \mathrm{Y})$. The only repeated source in the top 10 places is the Journal of Business Ethics, showing again its referential role in this academic field.

The most cited paper in relative terms (Delmas and Burbano, 2011), gathering the ideas of the previous literature, classifies the drivers of greenwashing into three different groups (external, organizational and individual), generating a framework which has been the basis of many later studies. The most cited paper in absolute terms ( 457 cites) is the work of Laufer (2003), which states that the problems faced by firms when developing accurate responsible information are the same ones that they have to face when trying to accomplish the law.

Dealing with agriculture, food industry and food retail, Sirieux et al. (2013), the most cited work about greenwashing related with food retail, positioned in the 12th place of citations, study the perception of the consumers about sustainable food labels compared and combined with other different kinds of labels (such as nutritional facts ...).

\subsection{Relational techniques: co-word analysis}

Relational techniques, such as co-word analysis, are used to identify patterns and detect hot topics inside a research field. Co-word analysis provides an insight into the main themes and research trends, studying the most frequent keywords. "When words frequently co-occur in
Bibliometric analysis of greenwashing

\begin{tabular}{|c|c|c|c|c|c|}
\hline Rank & $\begin{array}{l}\text { Name of } \\
\text { author }\end{array}$ & $\begin{array}{l}\text { Country of } \\
\text { author }\end{array}$ & University/Institution & Number of publications & \\
\hline 1 & Lyon, T.P. & USA & University of Michigan & 5 & \\
\hline 2 & Chen, Y.S. & China & China three Gorges University & 4 & \\
\hline 3 & Font, X. & UK & University of Surrey & 4 & \\
\hline 4 & Siano, A. & Italy & University of Salerno & 4 & \\
\hline 5 & Testa, F. & Italy & Scuola Superiore Sant'Anna & 4 & \\
\hline 6 & Vollero, A. & Italy & University of Salerno & 4 & \\
\hline 7 & Braga, S.S. & Brazil & Universidade Estadual Paulista & 3 & \\
\hline 8 & Correa, C.M. & Brazil & Universidade Estadual Paulista & 3 & \\
\hline 9 & Da Silva, D. & Brazil & Universidade Estadual de & 3 & \\
\hline & & & Campinas & & Table 2. \\
\hline 10 & Du X.Q. & China & Xiaomen University & 3 & Most prolific authors in \\
\hline 11 & Iraldo, $\mathrm{F}$. & Italy & Scuola Superiore Sant'Anna & 3 & greenwashing \\
\hline
\end{tabular}


BFJ
123,13

\begin{tabular}{|c|c|c|c|c|c|c|}
\hline $\mathrm{R}$ & Title & Authors & Year & Journal & $\mathrm{TC}$ & $\begin{array}{l}(\mathrm{C} / \\
\mathrm{Y})\end{array}$ \\
\hline 1 & The drivers of greenwashing & Delmas and Burbano & 2011 & $\begin{array}{l}\text { California } \\
\text { management } \\
\text { review }\end{array}$ & 363 & 40.3 \\
\hline 2 & $\begin{array}{l}\text { Greenwash: Corporate } \\
\text { environmental disclosure under } \\
\text { threat of audit }\end{array}$ & Lyon and Maxwell & 2011 & $\begin{array}{l}\text { Journal of } \\
\text { economics and } \\
\text { management } \\
\text { strategy }\end{array}$ & 293 & 32.6 \\
\hline 3 & $\begin{array}{l}\text { Greenwash and green trust: The } \\
\text { Mediation effects of green } \\
\text { consumer Confusion and green } \\
\text { perceived Risk }\end{array}$ & Chen and chang & 2013 & $\begin{array}{l}\text { Journal of business } \\
\text { Ethics }\end{array}$ & 198 & 28.3 \\
\hline 4 & $\begin{array}{l}\text { Social accountability and } \\
\text { corporate greenwashing }\end{array}$ & Laufer & 2003 & $\begin{array}{l}\text { Journal of business } \\
\text { Ethics }\end{array}$ & 457 & 26.9 \\
\hline 5 & $\begin{array}{l}\text { Corporate social responsibility } \\
\text { in the banking industry: Motives } \\
\text { and financial performance }\end{array}$ & Wu and Shen & 2013 & $\begin{array}{l}\text { Journal of banking } \\
\text { and Finance }\end{array}$ & 188 & 26.9 \\
\hline 6 & $\begin{array}{l}\text { How sustainability ratings } \\
\text { might deter "greenwashing": A } \\
\text { closer look at ethical corporate } \\
\text { communication }\end{array}$ & $\begin{array}{l}\text { Parguel, Benoit- } \\
\text { Moreau and } \\
\text { Larceneux }\end{array}$ & 2011 & $\begin{array}{l}\text { Journal of business } \\
\text { Ethics }\end{array}$ & 217 & 24.1 \\
\hline 7 & $\begin{array}{l}\text { A research note on standalone } \\
\text { corporate social responsibility } \\
\text { reports: Signaling or } \\
\text { greenwashing }\end{array}$ & $\begin{array}{l}\text { Mahoney, Thorne, } \\
\text { Cecil and LaGore }\end{array}$ & 2013 & $\begin{array}{l}\text { Critical } \\
\text { perspectives on } \\
\text { accounting }\end{array}$ & 161 & 23.0 \\
\hline 8 & $\begin{array}{l}\text { Perceived greenwashing: The } \\
\text { interactive effects of green } \\
\text { advertisement and corporate } \\
\text { environmental performance on } \\
\text { consumer reactions }\end{array}$ & $\begin{array}{l}\text { Nyilasy, } \\
\text { Gangadharbatla and } \\
\text { Paladino }\end{array}$ & 2014 & $\begin{array}{l}\text { Journal of business } \\
\text { Ethics }\end{array}$ & 134 & 22.3 \\
\hline 9 & $\begin{array}{l}\text { Legitimizing negative aspects in } \\
\text { GRI-Oriented sustainability } \\
\text { reporting: A Qualitative analysis } \\
\text { of corporate disclosure } \\
\text { strategies }\end{array}$ & Hahn and Luelfs & 2014 & $\begin{array}{l}\text { Journal of business } \\
\text { Ethics }\end{array}$ & 132 & 22.0 \\
\hline 10 & $\begin{array}{l}\text { Corporate social responsibility: } \\
\text { The disclosure-performance gap }\end{array}$ & $\begin{array}{l}\text { Font, Walmsley, } \\
\text { Cogotti, McCombes } \\
\text { and Hausler }\end{array}$ & 2012 & $\begin{array}{l}\text { Tourism } \\
\text { management }\end{array}$ & 145 & 18.1 \\
\hline 12 & $\begin{array}{l}\text { Consumer's perception of } \\
\text { individual and combined } \\
\text { sustainable food labels: a UK } \\
\text { pilot investigation }\end{array}$ & Sirieix & 013 & $\begin{array}{l}\text { International } \\
\text { journal of } \\
\text { consumer studies }\end{array}$ & 102 & 14.6 \\
\hline \multicolumn{7}{|c|}{ Note(s): TC: Total citations; C/Y: Citations per Year } \\
\hline
\end{tabular}

documents, it means that the concepts behind those words are closely related. It is the only method that uses the actual content of the documents to construct a similarity measure" (Zupic and Čater, 2015, p. 6).

As it was previously stated, we can identify three stages in the development of the literature: 1999-2010 (ground-setting); 2011-2015 (trail-blazing) and 2016-2020 (remarkable growth). In order to provide a detailed overview about the evolution of the topics, three co-word analyses were conducted.

In total, 32 articles related with greenwashing were published in the ground-setting period (1999-2010). These papers include a total of 111 keywords. In order to represent the 
knowledge structure, the map shown by Figure 2 considers the terms present in at least 2 publications. In this period, greenwashing was not a main concern for the literature yet, so it started to appear in different works mainly related with CSR. In fact, the keyword "greenwashing" has the lowest link strength of the ones included in this period.

As it was commented before, maybe the studies about CSR and sustainable development, gathered in the red cluster, were the origin of the academic concern about greenwashing. This is obviously linked with the environmental impact of the activities of the firms (such as construction), gathered in the green cluster; as well as with the legitimacy of the businesses, derived from their ethical behavior, referred in the blue cluster.

During the trail-blazing period (2011-2015) there was a significant increase in the number of articles. The 97 papers published in these years include 559 keywords. Figure 3 considers the 18 terms present in a minimum of 4 publications. A substantial change can be remarked: greenwashing appears in the core of the map, ceasing to be a consequence of the study of other subjects. Therefore, "greenwashing" is the main keyword, while CSR remains as a key issue. The claim for "sustainability" also gains importance as one of the main drivers of the information disclosure of firms.

The map reveals the presence of 4 different clusters. The yellow one is the smallest considering the number of keywords, but possibly the strongest regarding the internal and external links with other clusters. During this period, sustainability issues gained more importance as a relevant research topic for academics. So, it should be noted that the relationship sustainability-greenwashing, in the yellow cluster, is strengthened compared with previous years and is central in the academic concerns about greenwashing in this period. "Ethics" remains as one of the drivers of the academic literature about this topic.

The node "greenwashing" is also closely and strongly related with "management" and "corporate social responsibility", the two key terms included in the red cluster, which has mainly business management associations ("reputation", "information" or "firm"). The growing relevance of a stakeholder approach in business management has a clear impact in the literature, which is increasingly caring about the perception that these interest groups may have about the actions of a company. This cluster also shows the relevance of "information", "consumer" and "consumption", which seems reasonable, as when customers perceive a firm as socially responsible they may be more willing to buy its products, even at a higher price (Grimmer and Bingham, 2013).

These impressions of the stakeholders may be also based on one critical aspect about greenwashing, the quality of the information disclosed. So, the green cluster includes terms such as "communication" or "environmental disclosure", which should be the basis of the

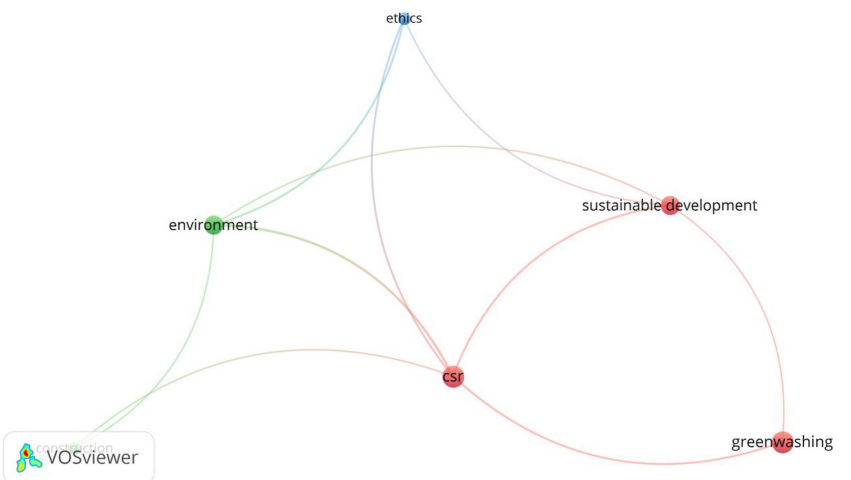

Figure 2.

Co-occurrence network of keywords in the field of greenwashing (1999-2010)

Bibliometric analysis of greenwashing 
$\mathrm{BFJ}$

123,13

\section{4}

Figure 3.

Co-occurrence network of keywords in the field of greenwashing (2011-2015)

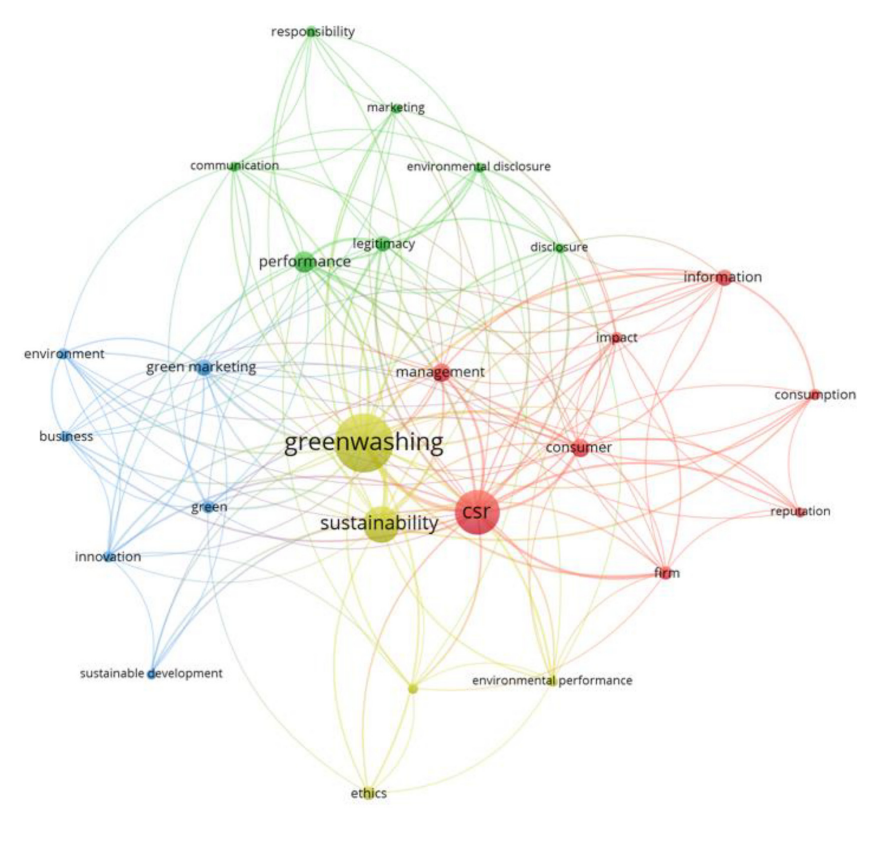

"legitimacy" of a company in front of the main stakeholders and, consequently, it's "performance".

The blue cluster deals mainly with the actions required to put responsibility into practice. So, some terms such as "innovation", "sustainable development", "green" and "environment" are especially relevant. The presence of "green marketing" reflects that it is also possible to use the real actions and behaviors of a company to improve its image in the face of customers without greenwashing.

Finally, the remarkable growth period (2016-2020) has witnessed a definitive bloom of the publications focused on greenwashing. The 222 papers published in this period include 1,288 keywords. Figure 4 maps them, including the 26 terms which can be found in at least 10 publications.

As can be seen, the "greenwashing" node has a central position in the network, evidencing the proximity to the rest of nodes and therefore, the current relevance of the topic. According to this, recent literature maintains its interest in the relationship between "greenwashing" and "corporate social responsibility".

Some of the trends shown in the trail-blazing period are firmly established and have been developed along these last years. So, the red cluster is mainly related with stakeholder management ("governance", "climate change", "corporate social responsibility”, "sustainability", "pollution" ...). Inside this group we can also find "strategy" and "performance", reinforcing and signaling the critical role of the Environmental Social and Corporate Governance (ESG) practices of "businesses" in the "management" of companies nowadays.

The responsible behavior of a firm does not grant an adequate image in the mind of the stakeholders. An appropriate communication strategy is needed to show the interest groups what a firm really does. The blue cluster, which includes terms such as "disclosure", "environmental performance" and "quality" gathers the main issues that could be required to gain "legitimacy" in front of the society. 


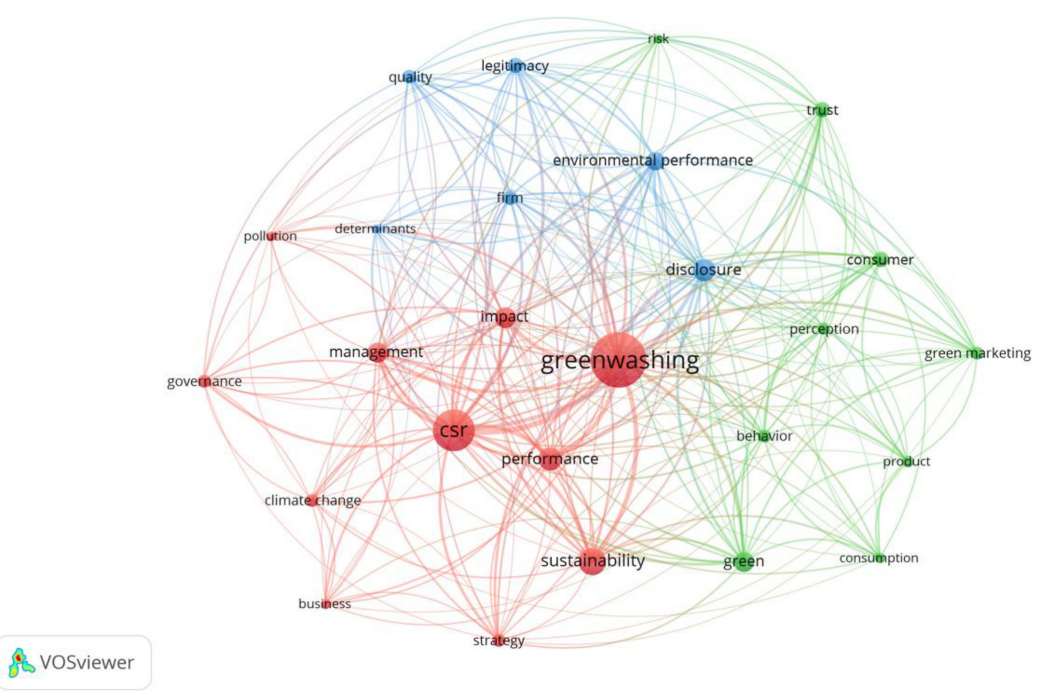

Bibliometric analysis of greenwashing

555

Figure 4. Co-occurrence network of keywords in the field of greenwashing

(2016-2020)

Finally, the green cluster is mainly marketing oriented. Different tools and information channels that could be used to disseminate greenwashing and achieve better purchase intentions and brand attitudes are explored here. Consequently, terms like 'consumer', 'perception', 'behavior', 'trust' or 'green marketing' are included.

Considering the analysis of the topics boarded by the literature in the most recent years, we could state that there are currently three main pillars, which are clearly intertwined, in the academic research about greenwashing: management (related with a stakeholder approach), audit (mainly concerned about the disclosure of information) and marketing (especially focused on one stakeholder, the consumer).

\section{A closer look at the academic research about greenwashing in agriculture, food industry and food retail}

Amongst the 351 papers selected for this bibliometric analysis, just 19, gathered in Table 4, are directly related with agriculture, food industry or food retail. This proportion is low if we consider the frequent presence of these industries in the mass media, associated with potential greenwashing practices. Also, the importance of the studies about food packaging (Vila-Lopez et al., 2021) could have generated more literature linked with greenwashing.

It must be remarked that just two of these 19 papers (Francis, 2004; Francis et al., 2007) were published before 2010, which means a low presence of the industry in the ground-setting period of the literature about greenwashing. Therefore, a first conclusion of this analysis is the presence of an interesting research opportunity: there is a need to get deeper into the study of greenwashing in these sectors.

Regarding agriculture, we can find three topics: the adoption of sustainable practices by the production units, especially the small farms; the effect of supranational organizations on the sustainability of the industry through their policies; and the impact of certification programs, contributing to greening, or to greenwashing, the production. So, the studies published in this sector are especially related with sustainability and legitimacy, but they do not get mainly concerned about the perception of the final customer.

Inside the first topic we can locate the works of Bager and Lampin (2020) about the adoption of sustainable practices in the coffee industry; Francis (2004), dealing with the 


\section{$\mathrm{BFJ}$ 123,13}

$\underline{556}$

\begin{tabular}{|c|c|c|}
\hline & Reference & Objective \\
\hline 1 & Alexander (2019) & Impact of the definition of climate-smart agriculture by the global Alliance \\
\hline 2 & Alons (2017) & $\begin{array}{l}\text { Presence of environmental policy integration in the common agriculture policy } \\
\text { (CAP) of the EU }\end{array}$ \\
\hline 3 & $\begin{array}{l}\text { Bager and Lambin } \\
(2020)\end{array}$ & Adoption of sustainable practices by the companies of the coffee industry \\
\hline 4 & Dai et al. (2011) & Green ads' distribution and greenwashing characteristics and practices \\
\hline 5 & DeFries et al. (2017) & Impact of voluntary certification programs for small farms on sustainability \\
\hline 6 & $\begin{array}{l}\text { Elving and Steenhuis } \\
\text { (2014) }\end{array}$ & Impact of an industry green label on the perceptions of consumers \\
\hline 7 & Francis et al. (2007) & Relationship between the size of a farm and the adoption of green practices \\
\hline 8 & Francis (2004) & $\begin{array}{l}\text { Assumptions made by corporations about the economic, environmental and } \\
\text { social dimensions of agricultural sustainability }\end{array}$ \\
\hline 9 & Gider and Hamm (2019) & $\begin{array}{l}\text { How consumers deal with the CSR information delivered to them through the } \\
\text { corporate websites of food producers and retailers }\end{array}$ \\
\hline 10 & Gosselt et al. (2019) & Interaction between external CSR labels and internal CSR claims \\
\hline 11 & Guyader et al. (2017) & $\begin{array}{l}\text { How retailers can attract consumers' visual attention and increase sales of eco- } \\
\text { friendly products displaying relevant information }\end{array}$ \\
\hline 12 & Houghton et al. (2018) & $\begin{array}{l}\text { Some positive environmental claims can, in fact, be greenwashing when they } \\
\text { concern a product considered to be harmful, as tobacco }\end{array}$ \\
\hline 13 & Houghton et al. (2019) & $\begin{array}{l}\text { Some positive environmental claims can, in fact, be greenwashing when they } \\
\text { concern a product considered to be harmful, as tobacco }\end{array}$ \\
\hline 14 & Nguyen et al. (2019) & $\begin{array}{l}\text { Mediation effects of green scepticism and moderating effects of information } \\
\text { and knowledge in the relationship between greenwashing and green purchase } \\
\text { intentions }\end{array}$ \\
\hline 15 & Saber and Weber (2019) & $\begin{array}{l}\text { Quality and approach of reporting, considering how German grocery retailers } \\
\text { report negative aspects and which communicative legitimation strategies they } \\
\text { apply }\end{array}$ \\
\hline 16 & $\begin{array}{l}\text { Schuldt and Hannahan } \\
\text { (2013) }\end{array}$ & $\begin{array}{l}\text { Analysis of the relationship of environmental concern and the evaluation of } \\
\text { organic food }\end{array}$ \\
\hline 17 & Sirieix et al. (2013) & Perceptions of sustainable labels vs. other labels such as nutrition ones \\
\hline 18 & Wagner (2015) & Semiotics of food packaging \\
\hline 19 & $\begin{array}{l}\text { Yarosh and Mitina } \\
\text { (2018) }\end{array}$ & $\begin{array}{l}\text { Certainty or not (greenwashing) of the claims of some organic food and non- } \\
\text { food products }\end{array}$ \\
\hline
\end{tabular}

\section{Table 4.}

The academic literature about greenwashing in agriculture, food industry and food retail impact of corporate agriculture on sustainability; and Francis et al. (2007), who studied the influence of the size of a farm in the adoption of sustainable practices.

Alexander (2019) analyzed the impact of the Global Alliance for Climate-Smart Agriculture on sustainability. Alons (2017) studied the inclusion of the Environmental Policy Integration in the Common Agriculture Policy (CAP) of the EU through the analysis of the historical evolution of the CAP. Finally, DeFries et al. (2017) focused on the effects of the adoption of voluntary certification programs for small farms of tropical commodities.

The main concern of the papers related with the food processing industry is related with labels and packaging, considering both the information they reveal about the product and the impressions they cause on the final customers. Organic food plays the main role in some of these studies. So, marketing and communication arise here as the main areas of concern.

Elving and Steenhuis (2014) studied the impact that an industry label has on consumers. In a relatively close approach, Gosselt et al. (2019) studied the interaction between internal CSR claims and external labels. Wagner (2015) is interested in the semiotics of food packaging and the images that can be caused by symbols, icons and barcodes. Finally, two studies carried out by the same research team (Houghton et al., 2018, 2019) stress that all the efforts of the tobacco industry, especially in the packaging, are in fact greenwashing, as they try to save the face of a harmful product. 
Organic food caught the attention of three studies: Yarosh and Mitina (2018), who study the certainty of the claims made by the producers of organic food in Crimea; Nguyen et al. (2019), who deal with the mediating role of green skepticism in the relationship between greenwashing and green purchase intentions; and Schuldt and Hannahan (2013), who conducted two studies analyzing the role of the personal degree of environmental activism in the perception of organic products.

Only three articles have considered the role of greenwashing in food retail. While two of them (Gider and Hamm, 2019; Saber and Weber, 2019) deal with the disclosure of sustainability information made by food retailing companies, Guyader et al. (2017) are more concerned with marketing, and specifically, on how the retailers can direct the attention of the consumers to eco-friendly products.

After this short review, the literature gap can be identified more precisely. There are no specific studies related with stakeholder management in any of these industries, as the attention has been focused on the analysis of the perception of the final customer. Also, the audit and information disclosure perspective could be an interesting point of view to study the food processing industry.

Anyway, as it was stated previously, the low number of papers in this area, along with the importance of sustainability in these sectors and the concentration of the papers in the last two years (7 out of 19) is a signal of an imminent burst in the literary production.

\section{Conclusions}

Greenwashing is a practice used by some firms, which combines a poor environmental performance with a positive communication about it (Delmas and Burbano, 2011). Academic research in this field of study has grown in parallel with society and media concern about these practices. In fact, the topic is relevant for practitioners and raises challenging issues and research opportunities related with many academic disciplines (Lyon and Montgomery, 2015).

The purpose of this article is to provide with an overview of the research about this form of corporate disinformation. In order to fulfill this objective, we have carried out a bibliometric study to determine the intellectual, thematic and conceptual structure of the research topic, considering the evolution of the literature from an initial ground-setting period to the current burst in the academic interest. This review and synthesis of the literature shows that greenwashing is a topic encompassing a variety of theories, approaches and actors. Thus, it remains an evolving area that requires further research and reflection.

There is an undeniable growing trend in the academic interest, which reflects the increasing concern of the society about this topic (Delmas and Burbano, 2011; Antunes et al., 2015; Wolniak and Habek, 2015). The relatively low concentration in terms of authors reveals the existence of a huge number of research teams currently working in this area. Regarding the sources which include these papers, the pioneer and clearly leading role of the Journal of Business Ethics is reinforced by some other prominent journals. The literature is grounded on the areas of management, with a special concern about ESG issues; marketing and communication, focused on the impact of the information revealed on the perception of the customers; audit, which analyses information disclosure; and sustainability and environmental management. As for the most cited papers, the literature about greenwashing has built its own classical references, such as Delmas and Burbano (2011), Laufer (2003), Lyon and Montgomery (2015) and Seele and Gatti (2017).

The co-word analysis reveals a clear evolution from the ground-setting period, when the concern about greenwashing appeared as a result of the analysis of CSR, to the trail-blazing stage, when greenwashing became an autonomous research field, outlining the streams 
BFJ

123,13

(consumer perception, information disclosure, stakeholder management ...) that have been developed in the remarkable growth period.

It is also interesting to address greenwashing practices in different industries. In this paper, we have specifically focused on greenwashing practices in agriculture, food industry and food retail, areas of major impact of these inadequate practices. The main concern of the papers dealing with greenwashing in agriculture is the need for sustainability, while the research about greenwashing in the food industry is specially linked with the perceptions of the consumers, mainly through the packaging and labels. Finally, the scarce studies that analyze greenwashing in the food retail deal mainly with the information disclosure of companies. Our analysis shows a relatively scarce academic presence of the study of greenwashing in these industries, which reveals a clear research opportunity in an important area of concern for the society. This gap is specially related with stakeholder management, as no specific attention has been paid to this topic in these sectors.

The main limitations of this paper must be mentioned. The relatively limited sample of documents, especially in the first period, has restricted the interpretation of our findings. Also, only WoS database was selected, which may have reduced the number of results obtained. Finally, as a characteristic feature of bibliometric techniques, the interpretation of the maps is, to a certain extent, subjective.

Notwithstanding these limitations, we consider that this work helps to stimulate further interest in greenwashing as a research topic. In fact, we call for more in-depth analysis of the relationship between sustainable growth and green marketing strategies to identify greenwashing practices. Research is also needed to identify typologies of selective disclosure of information. There is a need to explore not only the financial performance derived from these practices at a given moment, but also the long-term sustainability of this behavior: literature lacks analysis about the effect of selective disclosure on other stakeholders different from consumers, like employees, investors or suppliers.

The increasing importance of the academic production about greenwashing is just the reflection of the growing concern of society not only about the impact of corporate activities over the environment, but also about the need for true, complete and clear information about these practices and their potential impact. So, the development of scientific knowledge about greenwashing becomes a piece of a virtuous circle, which puts this social claim in the spotlight of business management studies, helping in turn to fight greenwashing and, this way, to reduce the environmental impact of corporate activities: studying greenwashing helps to reduce its frequency, and therefore, heals the planet.

\section{References}

Alexander, S. (2019), "What climate-smart agriculture means to members of the Global Alliance for climate-smart agriculture", Future of Food-Journal on Food Agriculture and Society, Vol. 7 No. 1, pp. 21-30, doi: 10.17170/kobra-2018122073.

Alons, G. (2017), "Environmental policy integration in the EU's common agricultural policy: greening or greenwashing?", Journal of European Public Policy, Vol. 24 No. 11, pp. 1604-1622, doi: 10.1080/ 13501763.2017.1334085.

Antunes, D., Santos, A. and Hurtado, A. (2015), "The communication of the LCA: the need for guidelines to avoid greenwashing”, Espacios, Vol. 36 No. 5, p. 1.

Bager, S.L. and Lambin, E.F. (2020), "Sustainability strategies by companies in the global coffee sector", Business Strategy and the Environment, Vol. 29 No. 8, pp. 3555-3570, doi: 10.1002/bse.2596.

Chen, Y.S. and Chang, C.H. (2013), "Greenwash and green trust: the mediation effects of green consumer confusion and green perceived risk", Journal of Business Ethics, Vol. 114 No. 3, pp. 489-500, doi: 10.1007/s10551-012-1360-0. 
Cobo, M.J., López-Herrera, A.G., Herrera-Viedma, E. and Herrera, F. (2012), "SciMAT: a new science mapping analysis software tool", Journal of the American Society for Information Science and Technology, Vol. 63 No. 8, pp. 1609-1630, doi: 10.1002/asi.22688.

Dai, X., Mao, J.H., Fam, K.S. and Jing, M.X. (2011), "The Investigation of Green Advertising in China -content analysis based on 1338 printed ads from 2000 to 2009", Tenth Wuhan International Conference on E-Business, Vols I and Ii, pp. 681-688.

DeFries, R.S., Fanzo, J., Mondal, P., Remans, R. and Wood, S.A. (2017), "Is voluntary certification of tropical agricultural commodities achieving sustainability goals for small-scale producers? A review of the evidence", Environmental Research Letters, Vol. 12 No. 3, doi: 10.1088/1748-9326/aa625e.

Delmas, M.A. and Burbano, V.C. (2011), "The drivers of greenwashing”, California Management Review, Vol. 54 No. 1, pp. 64-87, doi: 10.1525/cmr.2011.54.1.64.

Elving, W. and Steenhuis, V. (2014), "I make conscious misleading choices? On logos on food products and the influence on skepticism and buying intention", Tijdschrift Voor Communicatiewetenschap, Vol. 42 No. 2, p. 100.

Font, X., Elgammal, I. and Lamond, I. (2017), "Greenhushing: the deliberate under communicating of sustainability practices by tourism businesses", Journal of Sustainable Tourism, Vol. 25 No. 7 , pp. 1007-1023, doi: 10.1080/09669582.2016.1158829.

Francis, C.A. (2004), "Greening of agriculture for long-term sustainability", Agronomy Journal, Vol. 96 No. 5, pp. 1211-1215, doi: 10.2134/agronj2004.1211.

Francis, C., Elmore, R., Ikerd, J. and Duffy, M. (2007), "Greening of agriculture: is it all a greenwash of the globalized economy?", Journal of Crop Improvement, Vol. 19 Nos 1-2, pp. 193-220, doi: 10. 1300/J411v19n01_10.

Gider, D. and Hamm, U. (2019), "How do consumers search for and process corporate social responsibility information on food companies' websites?", International Food and Agribusiness Management Review, Vol. 22 No. 2, pp. 229-246, doi: 10.22434/IFAMR2018.0062.

Gomezelj, D.O. (2016), "A systematic review of research on innovation in hospitality and tourism", International Journal of Contemporary Hospitality Management, Vol. 28 No. 3, pp. 516-558, doi: 10.1108/IJCHM-10-2014-0510.

Gosselt, J.F., van Rompay, T. and Haske, L. (2019), “Won't get fooled again: the effects of internal and external CSR ECO-labeling”, Journal of Business Ethics, Vol. 155 No. 2, pp. 413-424, doi: 10.1007/ s10551-017-3512-8.

Grimmer, M. and Bingham, T. (2013), "Company environmental performance and consumer purchase intentions", Journal of Business Research, Vol. 66 No. 10, pp. 1945-1953, doi: 10.1016/j.jbusres. 2013.02.017.

Guyader, H., Ottosson, M. and Witell, L. (2017), “You can’t buy what you can't see: retailer practices to increase the green premium", Journal of Retailing and Consumer Services, Vol. 34, pp. 319-325, doi: 10.1016/j.jretconser.2016.07.008.

Houghton, F., Houghton, S., O’Doherty, D., McInerney, D. and Duncan, B. (2018), “Greenwashing' tobacco products through ecological and social/equity labelling: a potential threat to tobacco control", Tobacco Prevention and Cessation, Vol. 4, doi: 10.18332/tpc/99674.

Houghton, F., Houghton, S., O’Doherty, D., McInerney, D. and Duncan, B. (2019), “Greenwashing tobacco-attempts to eco-label a killer product", Journal of Environmental Studies and Sciences, Vol. 9 No. 1, pp. 82-85, doi: 10.1007/s13412-018-0528-z.

Laufer, W.S. (2003), "Social accountability and corporate greenwashing”, Journal of Business Ethics, Vol. 43 No. 3, pp. 253-261, doi: 10.1023/A:1022962719299.

Lyon, T.P. and Maxwell, J.W. (2011), "Greenwash: corporate environmental disclosure under threat of audit”, Journal of Economics and Management Strategy, Vol. 20 No. 1, pp. 3-41, doi: 10.1111/j.15309134.2010.00282.x.

Lyon, T.P. and Montgomery, A.W. (2015), “The means and end of greenwash”, Organization and Environment, Vol. 28 No. 2, pp. 223-249, doi: 10.1177/1086026615575332. 
BFJ 123,13

Marasco, A., De Martino, M., Magnotti, F. and Morvillo, A. (2018), "Collaborative innovation in tourism and hospitality: a systematic review of the literature", International Journal of Contemporary Hospitality Management, Vol. 30 No. 6, pp. 2364-2395, doi: 10.1108/IJCHM-01-2018-0043.

Marquis, C., Toffel, M.W. and Zhou, Y.H. (2016), "Scrutiny, norms, and selective disclosure: a global study of greenwashing”, Organization Science, Vol. 27 No. 2, pp. 483-504, doi: 10.1287/orsc.2015.1039.

Mulligan, P. (1999), "Greenwash or blueprint? Rio Tinto in Madagascar", IDS Bulletin, Institute of Development Studies, Vol. 30 No. 3, pp. 50-57, doi: 10.1111/j.1759-5436.1999.mp30003007.

Nguyen, T.T.H., Yang, Z., Nguyen, N., Johnson, L.W. and Cao, T.K. (2019), "Greenwash and green purchase intention: the mediating role of green skepticism", Sustainability, Vol. 11 No. 9, p. 2653, doi: 10.3390/su11092653.

Saber, M. and Weber, A. (2019), "Sustainable grocery retailing: myth or reality? A content analysis", Business and Society Review, Vol. 124 No. 4, pp. 479-496, doi: 10.1111/basr.12187.

Schuldt, J.P. and Hannahan, M. (2013), "When good deeds leave a bad taste. Negative inferences from ethical food claims", Appetite, Vol. 62, pp. 76-83, doi: 10.1016/j.appet.2012.11.004.

Seele, P. and Gatti, L. (2017), "Greenwashing revisited: in search of a typology and accusation-based definition incorporating legitimacy strategies", Business Strategy and the Environment, Vol. 26 No. 2, pp. 239-252, doi: 10.1002/bse.1912.

Sirieix, L., Delanchy, M., Remaud, H., Zepeda, L. and Gurviez, P. (2013), "Consumers' perceptions of individual and combined sustainable food labels: a UK pilot investigation", International Journal of Consumer Studies, Vol. 37 No. 2, pp. 143-151, doi: 10.1111/j.1470-6431.2012.01109.x.

Tateishi, E. (2017), "Craving gains and claiming "green" by cutting greens? An exploratory analysis of greenfield housing developments in Iskandar Malaysia”, Journal of Urban Affairs, Vol. 40 No. 3, pp. 370-393, doi: 10.1080/07352166.2017.1355667.

Van Eck, N.J. and Waltman, L. (2010), "Software survey: VOSviewer, a computer program for bibliometric mapping”, Scientometrics, Vol. 84 No. 2, pp. 523-538, doi: 10.1007/s11192-009-0146-3.

Vila-López, N., Kuster-Boluda, I. and Alacreu-Crespo, A. (2021), "Designing a low-fat food packaging: comparing consumers' responses in virtual and physical shopping environments", Foods, Vol. 10 No. 2, p. 211, doi: 10.3390/foods10020211.

Wagner, K. (2015), "Reading packages: social semiotics on the shelf", Visual Communication, Vol. 14 No. 2, pp. 193-220, doi: 10.1177/1470357214564281.

Wolniak, R. and Habek, R. (2015), "Reporting process of corporate social responsibility and greenwashing", Proceedings of the 15th International Multidisciplinary Scientific GeoConference SGEM, 2015, Albena, Bulgaria, Vol. 3, pp. 483-490.

Yarosh, O.B. and Mitina, E.A. (2018), "Studying the range of organic products and their distribution channels in the republic of Crimea", Regionologiya-Regionology Russian Journal of Regional Studies, Vol. 26 No. 1, pp. 90-107, doi: 10.15507/2413-1407.102.026.201801.90-107.

Zupic, I. and Čater, T. (2015), "Bibliometric methods in management and organization”, Organizational Research Methods, Vol. 18 No. 3, pp. 429-472, doi: 10.1177/1094428114562629.

\section{Corresponding author}

Rocio Gallego-Losada can be contacted at: rocio.gallego@urjc.es

For instructions on how to order reprints of this article, please visit our website:

www.emeraldgrouppublishing.com/licensing/reprints.htm

Or contact us for further details: permissions@emeraldinsight.com 